\title{
MEMBANGUN TATANAN SOSIAL MELALUI MORALITAS PEMBUMIAN AJARAN TASAWUF
}

\author{
Said Aqil Siradj \\ Fakultas Ushuluddin IAIN Sunan Ampel \\ Jl. Jenderal Ahmad Yani No. 117, Surabaya, 60237 \\ e-mail: said_aqil_sirodj@yahoo.com
}

\begin{abstract}
Abstrak: Perkembangan dunia kontemporer memperlihatkan kecemasan global umat manusia. Dengan kemampuan ilmu pengetahuan dan teknologi, tidak jarang manusia Modern melakukan hal-hal yang membahayakan kemanusiaan secara umum. Islam, dengan pandangan batiniahnya, menempatkan manusia sebagai makhluk Ilahiyah yang memiliki fungsi menjelmakan cahaya Ketuhanan di dalam kehidupan. Tulisan ini berusaha memperlihatkan bahwa pembumian ajaran-ajaran sufistik merupakan langkah signifikan dalam mengarahkan tatanan kehidupan dunia yang ramah, anggun dan penuh rahmat bagi sekalian alam. Penulis menyimpulkan bahwa bertasawuf pada hakikatnya adalah aktivitas berupa kesadaran manusia yang paling dalam tentang hubungan manusia dengan Tuhan, lingkungan dan sesamanya, yang terilhami oleh kualitas asmâ' dan shifat Allah dan kemudian terwujud dalam perilaku sosialnya.
\end{abstract}

\begin{abstract}
Developing Social Order through the Morality of the Application of Tasawuf Teachings. The rapid development of contemporary world results in global anxiety of humankind. With the prosperity of scince and technology, modern man has often performed actions that are against humanity in general. Islam with its esoteric perspective places man as godly creature functioning to existentiate the light of the Divine in life. In this writing is it is attempted to show that the application of sufistic teachings is a significant step in directing a friendly and peaceful life of the world order, merciful of God necessary for the whole creatures. The author concludes that in reality, applying tasawuf is an activity that reflect man's deep consciousness of his relationship with God, the environment and his fellow man inspired by the quality of the names and character of God which are then persevered in the social activities.
\end{abstract}

Kata Kunci: tasawuf, 'irfani, moralitas, $d z a w q$

\section{Pendahuluan}

Mencermati perkembangan Islam saat ini tampaknya begitu lekat dengan konflik sosial 
bertabur kekerasan, sehingga seakan mengantarkan pada kita sebuah kesimpulan ekstrim bahwa Islam tidak lagi mampu melahirkan masyarakat yang harmonis, apalagi kreatif. Ajaran Islam yang secara substansi semestinya adalah kumpulan doktrin yang mendamaikan digeser menjadi ajakan kekerasan. Islam yang secara hermeneutis adalah kumpulan teks yang membebaskan bermetamorfosis menjadi gumpalan yang rigid.

Ironisnya, penghayatan Islam yang demikian justru telah menginspirasi pandangan general tentang Islam, khususnya bagi non Muslim Barat, misalnya tulisan utama The New York Times yang berjudul "Seeing Green: The Red Menace is Gone. But Here's Islam" (Momok Hijau: Bahaya Merah telah Berlalu. Tetapi Sekarang Islam). ${ }^{1}$ Pesan yang terdapat di dalam tulisan tersebut adalah "Islam itu berbahaya."

Hal itu memunculkan keprihatinan umat Islam, sebab bagaimanapun Islam bukanlah reprentasi kekerasan, dan bukan pula berposisi vis-à-vis dengan non Muslim. Melainkan bagaimana Islam dengan moralitasnya mampu memberi cahaya damai di tengah-tengah masyarakat yang plural. Karenanya, demi membungkam sekaligus mencerahkan terhadap pandangan tentang Islam yang dangkal itu, maka pemahaman Islam perlu dikembalikan pada penilaian yang subtantif. Yakni diperlukan penyegaran pada tingkat keberagamaan yang lebih bersifat mendalam dan peresapan. Karena itu, tawaran tasawuf merupakan representasinya. Dengan cara bertasawuf memberikan keniscayaan dalam melihat ajaran Islam secara seimbang, harmonis. Dan dari berbagai tepian sehingga tidak merusak tatanan kosmis yang seimbang dan harmonis ini.

Dari persoalan tersebut, tulisan ini mengangkat nilai-nilai tasawuf sebagai tawaran yang diharapkan mampu bersenyawa dengan realitas sosial melalui spiritualitas agar memungkinkan adanya "penyiraman jiwa" dari kekeringan penghayatan iman dan kemiskinan batin, yang pada gilirannya nanti berperan sebagai arsitektur dalam tatanan sosial melalui moralitasnya.

\section{Menakar Epistemologi Tasawuf}

Epistemologi Barat modern tidak dapat dilepaskan dari sejarah manusia tiga abad terakhir ini, yang disebut dengan renaissance. Rene Descartes (1596-1650) sumber idenya telah menformulasikan sebuah prinsip, cogito ergo sum (aku berpikir, karena itu aku ada). ${ }^{2}$

${ }^{1}$ Dilansir Bruce B. Lawrence dari The New York Times Week in Review (21 Januari 1996). Lihat Bruce B. Lawrence, Islam Tidak Tungggal: Melepaskan Islam dari Kekerasan, terj. Harimukti Bagoes Oka (Jakarta: Serambi Ilmu Semesta, 2004), h. 9.

${ }^{2}$ Menurut Descartes (1596-1649), adalah keliru jika dikatakan bahwa kebenaran dapat dicapai dengan sesuatu yang sudah pasti dan tidak dapat diganggu gugat. Menurutnya, untuk mencapai kebenaran, seseorang harus melepaskan diri dari segala macam prasangka, termasuk prasangka yang berupa keyakinan dari dogma-dogma agama. Sebagai gantinya, ia harus menggunakan rasio dan pengetahuan berdasarkan fakta. Lihat Horald Titus, Persoalan-Persoalan Filsafat, terj. M. Rasjidi (Jakarta: Bulan Bintang, 1984), h. 78. 
Dengan prinsip ini, Descartes yang dikenal sebagai bapak rasionalisme telah menjadikan rasio sebagai satu-satunya kriteria untuk mengukur kebenaran. Pandangan ini terinspirasi oleh ide Plato (427-347SM) yang beranggapan, pengalaman indera tidak mampu memberikan pengetahuan yang pokok karena sifatnya yang berubah-ubah.

Sedang pandangan lain, bertolak belakang dengan pandangan di atas, diadopsi dari Aristoteles (384-322SM) yang beranggapan bahwa realitas sebenarnya adalah sesuatu yang dapat diindera, bukan diidea. Pandangan ini kemudian memunculkan John Locke (1632-1704) dengan penegasannya bahwa sumber ilmu pengetahuan adalah pengalaman atau empiris. Dalam perkembangannya, ide empiris ini dikembangkan oleh Thomas Hobbes (1588-1679), G. Berkeley (1685-1753) dan David Hume (1711-1779) yang kemudian diintroduksi oleh Auguste Comte (1798-1857) menjadi teori positivistik. Dalam pengertian positivistik ini maka kebenaran adalah yang tampak, sedang gejala-gejala di luar fakta adalah tertolak. ${ }^{3}$ Pandangan yang saling berlawanan antara rasionalisme dan empirisme tersebut menemukan sintesisnya melalui teori kritisme yang digagas oleh Immanuel Kant (1804). Menurut pandangannya suatu ilmu tidak pernah secara berat sebelah dapat dicari hanya pada kekuatan akal ilmiah sendiri melainkan justru membuka diri terhadap realitas empirik. ${ }^{4}$

Dalam garis besarnya, epistemologi yang berkembang di dunia Barat secara teoretik menampilkan tiga pola yang berbeda; pertama, teori korespondensi, yakni kebenaran atau keadaan benar itu berupa kesesuaian (korespondensi) arti yang dimaksud oleh suatu pendapat dengan apa yang sungguh merupakan halnya atau fakta. ${ }^{5}$ Dapat pula dikatakan, bahwa teori dalam kebenaran ini dapat didefinisikan sebagai kesetiaan pada realitas objektif. ${ }^{6}$ Kedua, teori konsistensi atau koherensi, yakni suatu putusan adalah benar apabila putusan itu konsisten (consistent) dengan putusan-putusan yang terlebih dahulu diterima dan ketahui benarnya. Putusan yang benar adalah suatu yang saling berhubungan (coherent) secara logis dengan putusan-putusan yang lainnya yang relevan. Dengan demikian, putusan yang satu dengan putusan yang lainnya saling berhubungan dan saling menerangkan. Dengan kata lain kebenaran adalah kecocokan (truth is consistency). ${ }^{7}$ Ketiga, teori pragmatis, yakni benar tidaknya suatu ucapan, dalil atau teori semata-semata bergantung berfaedah tidak ucapan, dalil, atau teori tersebut untuk bertindak dalam penghidupannya. Dengan kata lain, baik teori, hipotesis atau idea adalah benar apabila ia membawa kepada akibat yang memuaskan, apabila ia berlaku dalam praktik, apabila ia mempunyai nilai praktis.

3Ibid., h. 256.

${ }^{4}$ CA. Van Peusen, Susunan Ilmu Pengetahuan (Jakarta: Gramedia, 1989), h. 86.

${ }^{5}$ Louis O. Katsoff, Pengantar Filsafat, terj. Soejono Soemargono (Jogjakarta: Tiara Wacana, 2004), h. 242-243.

${ }^{6}$ Endang Saifuddin Anshari, Ilmu, Filsafat dan Agama (Surabaya: Bina Ilmu, 1987), h. 19. ${ }^{7}$ Ibid., h. 24. 
Kebenaran terbukti oleh kegunaannya, oleh hasilnya, oleh akibat-akibat praktisnya. Jadi, kebenaran ialah apa saja yang berlaku (works). ${ }^{8}$

Teori korespondesi yang dekat dengan mazhab realisme menempatkan kebenaran yang diraih tergantung pada realitas objektif. Dengan titik tolak yang demikian, terdapat keberatan terhadap teori korespondensi, yakni mengabaikan kebenaran di balik realitas objektif seperti kebenaran dalam peristiwa fenomena alam fatamorgana. Sedang teori konsistensi atau koherensi yang berkembang di bawah pengaruh Georg Wilhelm Friedrich Hegel (1770-1831) yang didukung mazhab idealisme menempatkan kebenaran subjektivitas, yakni kebenaran itu tergantung pada orang yang menentukan sendiri kebenaran pengetahuannya tanpa memandang keadaan riil peristiwa-peristiwa. Dengan kata lain, manusia adalah ukuran segala-galanya. ${ }^{9}$ Kebenaran yang demikian bagi Suhrawardî tetap tidak akan dapat mencapai kebenaran secara keseluruhan, karena ada kebenaran yang tidak dapat dicapai seperti tidak mampu menjelaskan selurus eksistensi di luar pikiran seperti soal warna, rasa, dan bayangan. Di saat yang sama teori konsistensi atau koherensi yang menyatakan bahwa atribut sesuatu harus didefinisikan oleh atribut yang lain akan menggiring pada proses tanpa akhir. Adapun teori pragmatisme yang menempatkan kebenaran disandarkan pada kegunaan (utility), dapat dikerjakan (workability) dan akibat atau pengaruh yang memuaskan (satisfactory consequences) pada gilirannya menghadirkan kritik terhadap kebenaran teori tersebut sebagaimana dikemukakan oleh Pierce, bahwa "suatu ide tidaklah disebut benar karena memuaskan, ia dikatakan memuaskan karena ia benar." 10

Konsepsi-konsepi sumber pengetahuan di atas merupakan representasi dasar epistemologi yang berkembang di dunia Barat. Karakteristik epistemologi yang dilahirkan hanya berkisar pada segala sesuatu yang dapat diserap pancaindera dan alat bantu belaka. Hal tersebut membenarkan penegasan Kant, pengetahuan adalah mungkin, namun metafisika adalah tidak mungkin, karena tidak disandarkan kepada pancaindera. ${ }^{11}$ Masih menurutnya, dalam metafisika tidak terdapat pernyataan-pernyataan sintetik-a priori seperti yang ada di dalam matematika, fisika, dan ilmu-ilmu yang berdasar kepada fakta empiris. Kant menamakan metafisika sebagai "a transcendental illusion" (ilusi transenden). Masih menurutnya lagi, metaphysical assertion are without epistemological value (pernyataan-pernyataan metafisika tidak memiliki nilai epistemologis). ${ }^{12}$ Kesimpulan dari epistemologi Barat yang demikian itu hanya kisaran dunia objektif dengan penekanan akal (rasio) dari pada alam perasaan (intuisi). Padahal sebenarnya masih banyak realitas lain yang memerlukan penelitian lebih mendalam sebagai upaya untuk mengungkapkan selubung misteri yang tidak semata-mata mampu diserap akal (rasio) maupun indera.

\section{${ }^{8}$ Ibid., h. 26-27.}

${ }^{9}$ Ibid., h. 24-25.

${ }^{10}$ Ibid., h. 30.

${ }^{11}$ Justus Harnock, Kant's Theory of Knowledge, trans. M. Holmes H (London: Macmillan, 1968), h. $142-145$.

${ }^{12}$ Ibid. 
Sementara itu dalam Islam, dengan bersandar pada Rasullah SAW. sebagai suri tauladan bagi seluruh manusia, telah ditegaskan bahwa pusat eksistensi manusia yang menentukan kualitas berpusat pada qalb (kalbu). Jika epistemologi Barat sebagai pengetahuan mengedepankan akal, maka sebenarnya telah membatasi potensi kecerdasan manusia hanya pada kecerdasan intelektual semata. Definisi cerdas dan berpikir manusia hanya dibatasi oleh bekerjanya simpul-simpul saraf di otak berdasarkan premis-premis logika yang telah dijadikan postulat sebagai kebenaran. Padahal dalam diri manusia terdapat kalbu sebagai anggota rohani yang mengendalikan proses kognitif manusia. Melalui kalbu, jiwa rasional (al-nafs al-nathîqah) dapat membedakan antara kebenaran (haqq) dengan kepalsuan (bathil). ${ }^{13}$

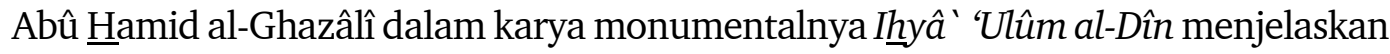
bahwa qalb (kalbu) adalah sarana pengetahuan intuitif (ma'rifah), bukan indera atau akal. ${ }^{14}$ Selanjutnya, ia menggambarkan kalbu sebagai sarana márifah sebagaimana dalam bentuk cermin, yakni pengetahuan yang muncul adalah pantulan gambaran realitas yang terdapat di dalamnya. Dengan demikian jika cermin kalbu itu tidak bersih, maka ia tidak akan memantulkan realitas-realitas pengetahuan. Menurutnya, yang membuat cermin kalbu tidak bening adalah hawa nafsu tubuh, di sisi lain ketaatan kepada Allah SWT. dan keberpalingan dari tuntutan hawa nafsu, justru akan membuat kalbu menjadi bening dan terang. ${ }^{15}$

Kemampuan mengolah kalbu inilah yang kemudian melahirkan realitas intuisi (intuision) dalam menjamah kebenaran (truth). Para sufi menyebut pengetahuan ini sebagai rasa yang mendalam ( $d z a w q)$ yang bertalian dengan perspektif batin. Dengan kata lain, pengetahuan intuitif merupakan pengetahuan yang dikaruniakan Tuhan dan dipatrikan pada kalbu seseorang sehingga tersingkap sebagian rahasia dan tampak sebagai realitas. Dengan kata lain perolehan pengetahuan ini bukan dengan jalan penyimpulan logis sebagaimana pengetahuan rasional, melainkan dengan jalan kesalehan (baca: sufi), karena seseorang memiliki kebeningan kalbu sehingga menghasilkan wawasan spiritual yang prima.

Proses sampainya qalb (kalbu) pada cahaya Tuhan terkait erat dengan konsep takhalli, tahalli dan tajallî. Dalam kondisi takhallî seseorang mengosongkan diri dari akhlak yang tecela dan perbuatan maksiat melalui taubat, dilanjutkan dengan tahallî di mana seseorang menghiasi perilakunya dengan akhlak yang mulia dan amal ibadah yang kemudian mengantarkan kepada kondisi tajallî di mana terbukanya hijab sehingga tampak jelas baginya cahaya Tuhan. Menurut Douglas V. Seere, dalam pengetahuan yang demikian, seseorang berada dalam kondisi yang amat sadar tentang kehadiran Yang Maha Riil (The condition of being over whelmingly aware of the presence of the Ultimity Real). Masih menurutnya, intuisi dalam mistik (sufi) memiliki implikasi yang lebih jauh, mungkin dapat menjelma menjadi persatuan aku dengan Tuhan pribadi (ittihhâd) ataupun kesadaran kosmis (wahdat al-wujûd). ${ }^{16}$

${ }^{13}$ S.M.N. al-Attas, The Concept Education in Islam (Kuala Lumpur: ISTAC, 1991), h. 14.

${ }^{14}$ Abû Hâmid al-Ghazâlî, Ihyyâ' 'Ulûm al-Dîn (Kairo: Musthafâ Bâbî al-Halâbî, t.t.), h. 3.

${ }^{15}$ Ibid., h. 12-13.

${ }^{16}$ Douglas V. Seere, "Mysticism," dalam Hand Book of Christion Theology (New York: World, 1958), h. 371-372. 
Dengan membandingkan karakteristik epistemologi di atas, maka dapatlah disimpulkan bahwa pandangan ilmiah yang ditawarkan oleh epistemologi Barat tampak sekali bersifat distorsif, dan dengan sendirinya terlindas oleh pandangan progresif tasawuf yang mampu memberikan makna mendalam tentang realitas. Misal dalam memandang alam semesta (kosmos) akan berkesimpulan realitas bukanlah satu-satunya, melainkan tanda-tanda dari "realitas sejati" yang ada di balik fenomena positif. Dengan kata lain, kosmos adalah cerminan "realitas sejati". Karena itu kosmos berfungsi sebagai tanda-tanda eksistensi Tuhan. Pandangan progresitas tersebut menemukan dasarnya dalam hhadis qudsi yang sering dikutip para sufi ketika menyelami realitas sejati, sebagaimana firman-Nya, "kuntu kanzan makhfìyan fa 'ahbabtu 'an u'rafa fa khalaqtu al-khalqa fabî 'arafûnî' (Aku adalah khazanah yang tersembunyi, dan Aku ingin diketahui, karena itu Aku menciptakan makhluk agar Aku diketahui).

Berangkat dari pandangan tersebut, para sufi memandang kosmos adalah tajallî (penampakan, representasi) dari Tuhan. Mereka berkesimpulan bahwa ada kaitan yang erat antara makhluk dengan Sang Khalik. Kaitan erat ini termanifestasi dalam konsep bahwa kosmos (alam semesta) beserta seluruh isinya dan apa saja yang berkaitan dengannya, tak lain adalah tajallî dari Allah. Dengan kata lain, realitas sejati yang bersifat spiritual telah diberikan bentuk ragawi oleh kosmos. Tegasnya, realitas samawi adalah tak berwujud dan bersifat spiritual, dan bumi memberinya bentuk ragawi. Analoginya, "ruh" tidak bisa berbuat banyak tanpa badan dan raga, yang berfungsi sebagai wahana atau sarana.

Progresivitas epistemologi tasawuf di atas juga selaras dengan titah al-Qur'an dalam berbagai ayat yang mengajak manusia agar menggunakan kemampuan dirinya untuk mengamati dan merenungkan segala peristiwa yang terjadi dalam kosmos ini, bahkan tentang hal ihwal dirinya sendiri. ${ }^{17}$ Karena di dalamnya terkandung bukti-bukti yang kuat dan meyakinkan tentang adanya Allah pencipta jagad raya. Jadi dalam epistemologi tasawuf, realitas dan kebenaran bukanlah semata-mata pikiran tentang alam fisik dan keterlibatan manusia dalam sejarah dan sosial, politik dan budaya sebagaimana yang ada di dalam epistemologi Barat mengenai dunia yang dibatasi kepada dunia yang dapat dilihat. Bagi tasawuf realitas dan kebenaran dimaknai berdasarkan kajian metafisis terhadap dunia yang tampak dan tidak tampak.

Sayangnya, tawaran epistemologi yang progresif tersebut oleh sebagian umat Islam kini justru sulit untuk dijamah, sebaliknya mereka hanya memandang realitas sejati sekadar dipahami sebagai simbol lalu dianggap seperti "patung" indah yang tak boleh disentuh tangan sejarah. Di sisi lain, cara pandang epistemologi Barat, khususnya positivistik yang jelas-jelas tidak mampu memberikan nilai rasionalitas terhadap ajaran-ajaran agama justru ditampilkan dalam memahami ajaran-ajaran agama Islam, sebagaimana pandangan 'skripturalisme' yang menempatkan asumsi; "semakin harfiah seseorang memahami sabda

${ }^{17}$ Q.S. al-Fushilât/41: 53; Q.S. al-Kahfi/18: 51; Q.S. al-Rûm/30: 8; dan Q.S. Yâsin/36: 36. 
Tuhan, semakin dekat orang tersebut kepada kehendak-Nya; semakin ia asyik dan sembrono dalam penafsiran non literal, maka semakin jauh ia dari kehendak-Nya". Asumsi ini dengan sendirinya mengeliminasi konteks yang tak terbatas sebagai realitas lain tertutup akibat berdasar pada teks yang terbatas.

Cara pandang tersebut identik dengan positivistik yang telah disinggung sebelumnya. Dalam praktiknya, aktualisasi cara pandang tersebut mengantarkan pada pemerkosaan nilai-nilai substansi agama ke dalam bingkai, meminjam bahasa Abou El Fadl, otoritarianisme, yakni "tindakan mengunci dan mengurung kehendak Tuhan atau kehendak teks, dalam sebuah penetapan makna, dan kemudian menyajikan penetapan tersebut sebagai sesuatu yang pasti dan absolut, dan menentukan." ${ }^{18}$ Alhasil, akses terhadap kerangka kerja yang demikian senyatanya mengarah pada keyakinan absolutisme yang tidak kenal kompromi, yakni tidak toleran terhadap berbagai sudut pandang yang berkompetisi dan memandang realitas plural sebagai bentuk kontaminasi atas kebenaran sejati.

\section{Bertasawuf sebagai Sandaran Cermin Tuhan}

Sebagaimana paparan singkat di atas bahwa epistemologi tasawuf telah menyandarkan pada ma'rifah (intuisi) untuk menggapai hakikat-hakikat batin yang tidak tercapai kesempurnaannya hanya oleh berpikir yang bekerja hanya pada simpul-simpul saraf di otak. Adapun puncak dari bertasawuf dengan sarana ma 'rifah-nya adalah menyadarkan manusia bahwa dirinya adalah merupakan manifestasi Tuhan. Semboyannya adalah; "awal kesempurnaan adalah ma 'rifat tentang manusia, sedangkan ma'rifat Allâh adalah puncaknya". ${ }^{19}$ Tegasnya, ma 'rifat adalah sarana sampai pada keyakinan atas kesadaran penyatuan manusia dengan Tuhan.

Kondisi seperti itu disebut dengan fanâ'. Dalam pengertiannya, fanâ' adalah bergantinya sifat-sifat kemanusian dengan sifat ketuhanan. Untuk memudahkan pengertian esensi fanâ' ada baiknya mengetahui penjelasan tipologi al-fanâ' 'an al-nafs secara ringkas dari alQusyayri, "Ketika sufifanâ' dari diri dan sifat-sifat pribadinya lantaran kesadarannya terfokus pada sifat-sifat Tuhan, maka dia baqa' dalam penghayatan alam ghaib (kasyfal-hijâhb), lalu ketika sufi fanâ' dari penghayatan sifat-sifat Tuhan, maka dia baqa' dalam penyaksian Tuhan (ma'rifat Allâh), dan ketika pada puncak ma'rifah, maka sufi mengalami fanâ' al-fanâ. ${ }^{20}$

Kondisi fanâ' tersebut yang mengantarkan Abû Yazid al-Bustâmî (364 H/877 M) sebagai tokoh pencetus paham ittihâad. Ke-fanâ'-an telah membawa al-Bustâmî kepada

${ }^{18}$ Khaled Abou El Fadl, Speaking in God's Name: Islamic Law, Authority and Women (England: Oneworld Publications, 2003), h. 92.

${ }^{19}$ Said Aqil Siradj, Ma'rifatullah: Pandangan Agama-Agama, Tradisi dan Filsafat (Jakarta: éLSAS, 2003), h. 13-14.

${ }^{20} \mathrm{Abu}$ Qasim al-Qushayri, al-Risâlah al-Qushayriyah, diedit oleh Abd Qadir Mahmud (Kairo: Dâr al-Kutub al- Hadithah, 1974), h. 231. 
ittihâad. Fana's sendiri merupakan pra kondisi menuju ittihâad. Kesadaran yang terserap dan luluh ke dalam kesadaran serba Tuhan inilah yang merepresentasikan ittihâad. Ketika ittih $\underline{a} d$, sufi menyadari suatu wujud (Tuhan), sehingga dapat terjadi tukar peran antara sufi dan Tuhan; salah satu darinya dapat memanggil yang lain dengan kata-kata "Yâ anâ" (Hai aku). Dalam teks Arabnya kata-kata tersebut berbunyi, "fa yaqûlu al-wâhidu lil al-'âkhiri yâ anâ" (maka yang satu kepada yang lainnya mengatakan aku). Kondisi semacam ini pernah dialami oleh al-Bustâmî. Ungkapan yâ anâ yang dimaksud bukan al-Bustâmî itu sendiri, melainkan ia telah bersatu batin dan ruhnya dengan Tuhan melalui ke-fanâ'-an. Ungkapan al-Bustâmî dalam kondisi seperti itu disebut syathahât, yakni ekspresi pikiran dan cita rasa yang berkecamuk dalam hati para sufi. Ekspresi itu bersifat bebas dan spontan tanpa tunduk terhadap wilayah murâqabah atau aturan. Singkat kata, mentrasfer isyarat-dari batin ke zahir- dengan ucapan. ${ }^{21}$ Dengan demikian syathahât adalah ungkapan perasaan ego bahwa ia adalah Allah dan Allah adalah ego, sehingga berdiri di ambang kesatuan.

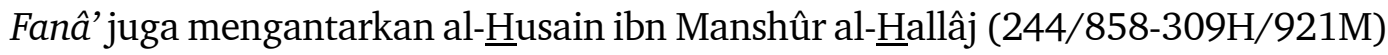
kepada paham hulûl. Tuhan, menurut al-Hallaj, adalah Yang Maha Cinta dan Kasih, cintakasih terhadap diri-Nya sendiri menjadi 'illah (sebab) adanya semua makhluk, termasuk Adam (manusia) sebagai ciptaan-Nya paling sempurna karena pada diri-Nyalah Tuhan muncul dengan sîrah-Nya (gambarNya). ${ }^{22}$ Atas dasar ini al-ㅌallâj menyakini bahwa dalam diri Tuhan ada natur kemanusiaan yang disebut nâsût, dan pada diri manusia ada natur ketuhanan yang dia sebut lâhût. Dengan demikian, al-Hallâj mengakui eksistensi dualisme. Tuhan selain memiliki natur lahut sekaligus juga natur nâsût, begitu pula manusia, selain mempunyai unsur nasut sekaligus unsur lâhût. Dengan kerangka pemikiran inilah persatuan antara sufi dan Tuhan dapat terjadi. Meski demikian persatuan figuratif dalam $\underline{h} u l u \hat{l}$ masih mengakui "perbedaan" dan "pemisahan" ruh Tuhan dengan ruh sufi. Dengan demikian pernyataan "Ana al- $\underline{H a q q " ~(A k u ~ Y a n g ~ M a h a ~ M u t l a k) ~ t i d a k ~ d a p a t ~ d i p a n d a n g ~ s e b a g a i ~ u c a p a n ~}$

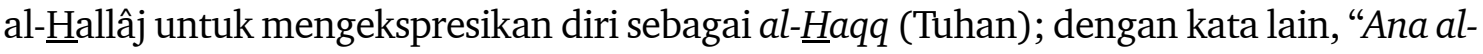
$\underline{H} a q q$ " sama sekali tidak berkonotasi pada pengakuan diri al-Hallaj sebagai Tuhan. Bahkan al-Hallaj sendiri secara tegas menolak adanya anggapan bahwa dirinya adalah identik

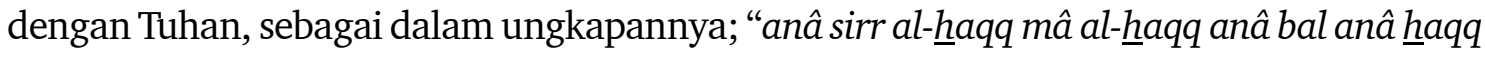
fafarriq baynanâ" (Aku adalah rahasia yang Maha Mutlak dan bukanlah yang Maha Mutlak itu aku. Aku hanya suatu yang Mutlak, maka bedakanlah antara kami).

Representasi dari dua tokoh sufi di atas terkait implentasi ma 'rifat-nya, tak pelak menimbulkan kontroversi yang tidak pernah ada habisnya. Komentar pedas dengan sendirinya hadir mengiringi baik ditujukan langsung kepada dua tokoh tersebut maupun

${ }^{21}$ Muhammad 'Abîd al-Jâbirî, Naqd al-Aqul al-Arabî, Bunyat al-'Aql al-Arabî: Dirâsah Tahlîiliyah Naqdiyah li Naz̄m al-Ma'rifah fĩ al-Thaqâfah al-Arabah (Beirut: Markaz al-Thaqafî al-'Arabî, 1993), h. 288.

22‘Abd al-Qâdir Mahmûd, al-Falsafah al-Sûfiyah fí al-Islâm (Kairo: Dâr al-Fikr al-'Arabî, 1967), h. 361. 
kalangan sufi pada umumnya, sebagaimana komentar Ibn al-Jauzi, "kaum sufi menamai ilmu mereka dengan ilmu batin dan menganggap ilmu syariat sebagai ilmu zahir. Mereka ini berada pada posisi bid'ah. Kasyf adalah omong kosong. Orang-orang zindiq tidak berani menolak syariat sebelum datang kaum sufi. Mereka datang dalam bentuk orang-orang lancang. Allah pasti mendengar orang-orang yang kosong dari kepastian. Mereka ini hanyalah sekelompok orang zindiq. ${ }^{23}$ Ibn Taimiyyah juga mengomentari tentang praktik tasawuf khususnya Ibn 'Arabî (dibahas kemudian) dengan komentarnya bahwa suatu paham yang mengatakan makhluk bagian dari Khaliq adalah kekufuran yang nyata. Hal ini merupakan ucapan musuh-musuh Allah; dari kaum Kristen, kelompok Rafidhah radikal dan sufi-sufi bodoh. Barang siapa menyakininya maka ia kafir. Orang mukmin yang ma 'rifat terhadap Allah SWT. dan mencintai-Nya memang memiliki derajat-derajat qurb dan keyakinan yang nyaris tidak bisa diungkapkan dan terdeteksi dengan ma 'rifat yang benar. Allah adalah Allah, dan hamba adalah hamba. Di dalam Zat-Nya tidak ada secuil pun makhluk-Nya, dan di dalam makhluk-Nya tidak ada secuil pun Zat-Nya. Tidak seorang pun yang ma 'rifat kepada Allah menyakini inkarnasi Rabb di dalam dirinya atau makhluk lain dan tidak pula bersatu dengannya. ${ }^{24}$

Komentar Ibn Taimiyyah tersebut mendapakan kritikan balik dari Mahmûd al-Ghurab dalam Syarh al al-Kalimât al-Shûfiyah. Menurutnya, Ibn Taimiyyah menyalahkan Ibn 'Arabî hanya bersandar pada pemahaman dari tulisan-tulisan Ibn 'Arabî bukan dari pemahamannya terhadap Ibn 'Arabî itu sendiri, meskipun tak menembus kejiwaan Ibn 'Arabî secara paripurna. Masih menurutnya, "orang yang memahami perkataan belum tentu memahami yang berkata, tapi orang yang memahami yang berkata sudah tentu memahami perkataan". Dengan demikian, kritikan sangat pedas Ibn Taimiyah tersebut didorong oleh ketidakmengertiannya terhadap Ibn 'Arabî sebagai seorang sufi yang berbicara atas nama ahli ma'rifat.

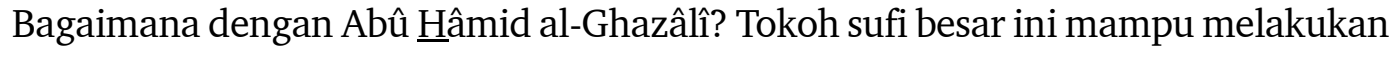
reapproachement terhadap kontroversi tasawuf pendahulunya dengan Islam yang berorientasi syari'ah, yakni dengan meminimalisir konflik dan mendamaikan keduanya. Menurut Abû al-Ala 'Afifi, ketika menyelami Misykat al-Anwâr, karya al-Ghazâlî memberi gambaran sikap final al-Ghazâlî terkait dengan masalah-masalah yang telah dibahasnya dalam karya-karyanya terdahulu. Dalam kitab tersebut ia berani dengan terang-terangan mengungkapkan apa yang tidak berani diungkapkannya dalam karya-karyanya terdahulu. Dalam kitab ini ia dekat dengan doktrin wah dah al-wujûd. Ia memandang bahwa tidak ada yang ada sebenarnya dalam wujud kecuali Tuhan, karena wujud segala sesuatu selain Dia adalah pinjaman atau berasal dari Dia; wujud pinjaman apa pun berada pada hukum atau sifat apa yang tiada. Karena itu alam pada hakikatnya tidak mempunyai wujud. ${ }^{25}$

${ }^{23}$ Siradj, Ma'rifatullah, h. 30-31.

${ }^{24}$ Ibid., 62-63.

${ }^{25}$ Abû al-Ala 'Afifî, "Tasdîr “Âmm," dalam Abû Hâmid al-Ghazâlî, Misykat al-Anwâr (Kairo: al-Dâr al-Qawmiyah, 1964), h. 7. 
Bagi al-Ghazâlî, wujud adalah cahaya dan ketiadaan adalah kegelapan. Yang paling berhak memiliki nama cahaya adalah "sumber" cahaya itu sendiri, "cahaya pertama," "cahaya yang sebenarnya," "Cahaya Terjauh dan Tertinggi," yang tiada cahaya di atasnya dan darinya turun cahaya kepada selainnya, Yaitu Allah. Nama cahaya untuk selain "Cahaya Pertama" adalah kiasan belaka, karena segala sesuatu selain Dia, bila dilihat dari dirinya, tidak mempunyai cahaya sama sekali. Cahaya pada segala sesuatu itu adalah pinjaman dari sesuatu yang lain. Cahaya yang sebenarnya adalah Dia yang di tangan-Nya penciptaan dan perintah, dan Dia adalah yang pertama memberi cahaya dan menjaga keberlangsungannya. Tidak sesuatu pun berbagi dengan Dia hakikat nama ini dan tidak pula kepemilikannya kecuali kiasan. Alam (kosmos) atau "apa yang selain Allah" pada dirinya adalah ketiadaan belaka dan wujud hakiki hanyalah Allah sebagaimana cahaya hakiki hanyalah Allah. ${ }^{26}$

Sementara itu wacana tentang manusia selaku tempat manifestasi Tuhan menjadi tuntas di tangan Muhy al-Dîn Ibn 'Arabî melalui penegasan paham wah̆dah al-wujûd. Baginya, wujud Allah adalah satu dalam Diri-Nya, tetapi muncul melalui tajallî sebagai beragam benda eksisten. Dengan kata lain, "wujud" disifatkan kepada Allah dari segi ketiadataraanNya, dan "eksistensi" disifatkan kepada-Nya dari segi keserupaan-Nya. Pada yang pertama, Dzat Allah tidaklah terketahui dan tak terjangkau-Yang Wajib Wujud melalui Diri-Nya. Pada yang kedua, Allah memanifestasikan Diri-Nya dalam "eksistensi menurut bentuk" (al-wujûd al-shûrî)- Nafas al-Rậman, yang "mengambil" bentuk seluruh benda eksisten di kosmos.

Ia yang ingin memasuki Allah hendaklah meninggalkan akalnya dan berpegang kepada syari'at, karena Allah tidaklah menerima pembatasan (taqyîd), di mana akal adalah terbatas. Milik-Nyalah tajallî dalam setiap bentuk sebagaimana "Dia menyusunmu sesuai dengan bentuk apa pun yang Dia kehendaki” (Q.S. al-Infithâr/82:8). Maka segala puji hanyalah milik Allah yang telah menyusun manusia menurut bentuk tertentu yang tidak membatasi dan tidak pula menentukan-Nya di dalam bentuk tersebut. Sebaliknya, kujadikan bagi-Nya apa yang memang milik-Nya sesuai pemberitahuan-Nya bahwa hal tersebut memang milik-Nya, yaitu tah "mengukur Allah dengan sebenar-benar ukuran-Nya" (Q.S. al-Anfâl/6: 91) kecuali Allah. Ia yang puas bersama Allah dalam apa yang Dia telah mensifati Diri-Nya dengannya pasti tidak akan membiarkan dirinya diatur oleh akalnya sendiri dari segi Kedirian-Nya. Maha Tinggi Allah dari hal tersebut.

Al- $\underline{H}$ aqq memiliki dua keterkaitan kepada wujud, yaitu keterkaitan-Nya kepada Yang Wajib Wujud dari Diri, dan keterkaitannya kepada "eksistensi menurut bentuk". Dialah yang bertajalli di dalamnya kepada para makhluk-Nya, karena mustahil bagi-Nya untuk bertajalli dalam "Yang Wajib Wujud dari Diri", karena manusia tidaklah memiliki mata yang dapat memahaminya. Baik dalam keadaan eksistensi maupun noneksistensi manusia,

${ }^{26}$ Ibid., h. 54-55. 
manusia tetap menjadi entitas yang kepadanya penguatan diberikan. Karena aturan posibilitas tidak pernah meninggalkan manusia, maka ia tidak pernah melihat-Nya kecuali melalui diri manusia itu-apa yang diberikan oleh realitas manusia. Maka tajallî-Nya pasti terjadi di dalam "eksistensi menurut bentuk", sebagai yang menerima tahawwul dan pergantian. ${ }^{27}$

Allah adalah Satu dalam Diri-Nya, sedangkan tajallî mengambil bentuk dari "yang banyak". Pluralitas manifestasi adalah kembali kepada nama-nama Ilahi - yang "satu" dan "banyak" di saat yang sama. Ibn 'Arabî menunjukkan hal ini ketika menafsirkan surat al-Ikhlâsh ayat pertama: "Dialah Allah Yang Satu"(Q.S. al-Ikhlâsh/112: 1), menunjuk kepada ahadiyyat al-ahad (Unitas Yang Satu), sedangkan ayat kedua: "Allah Maha Tempat Bergantung" (Q.S. al-Ikhlâsh/112: 2), menunjuk kepada fakta bahwa seluruh "hal banyak" adalah kembali kepada nama-nama dan bergantung kepadanya.

Inilah yang kemudian mengantarkan Ibn 'Arabî memiliki pandangan bahwa Allah merangkum sifat tanzîh (ketakterbandingan) dan tasybîh (keserupaan dan kedekatan). Pengejawantahan dari kedua sifat tersebut bisa diringkas oleh dua istilah kunci dalam al-Qur'an; hamba ('abd) dan wakil (khalîfah). Sifat tanzîh Allah, menjadikan manusia dan makhluk lainnya adalah hamba-hamba-Nya dan harus tunduk pada kehendak-Nya. Akan tetapi, berkenaan dengan sifat tasybîh, manusia mempunyai peran yang harus dimainkan, di mana manusia diciptakan dalam citra Allah yang semua kualitas-kualitas Allah dapat ditemukan dalam dirinya. Karena itulah, manusia bisa menjadi wakil (khalifah) Allah di muka bumi.

Dari konsep tasybîh di atas, maka secara mendasar menempatkan manusia sebagai cerminan Tuhan adalah bermoral, sebab bagaimana pun, hanya dalam diri manusia menurut definisi di atas citra Tuhan akan terefleksikan secara penuh. Konsepsi inilah yang dikembangkan para sufi yang mengisyaratkan hubungan yang begitu dekat antara manusia dengan Tuhan. Sementara itu di luar konsepsi tersebut, menganggap hubungan manusia dengan Tuhan bersifat formal dan berjarak; hubungan kaku antara yang superior dan yang inferior. Tuhan harus ditakuti dan ketakutan akan balasan Tuhan yang menentukan kesalehan sejati, inilah konsepsi yang dibangun di atas pandangan normatif.

\section{Tasawuf sebagai Arsitektur Moral dalam Membangun Tatanan Sosial}

Berbicara tentang watak manusia, Thomas Hobbes (1588-1679) dengan teorinya mengemukakan bahwa sifat dasar manusia adalah "homo homoni lupus" (manusia yang satu adalah serigala buat manusia yang lain) atau bellum monium coatra amnes (the war of all against: perang semua lawan semua). Teori Hobbes ini menunjukkan bahwa manusia dalam keadaan alamiahnya hanya ingin menaklukkan manusia lain. Hampir senada dengan Hobbes, tokoh yang mendewakan kematian Tuhan yakni Friedrich Nietzsche (1844-1900)

\footnotetext{
${ }^{27}$ Muhyy al-Dîn Ibn 'Arabî, Al-Futûhât al-Makkiyah, Vol. III (Kairo: al-Hay’ah al-Misriyah al-'Âmmah li al-Kitâb, 1972), 515.33, 516.14.
} 
berpandangan, "kehendak berkuasa adalah realitas sejati dan fitrah manusia". ${ }^{28}$ Artikulasi sifat dasar manusia yang seperti itu menarasikan akan keharusan semua orang menjadi tuan (baca: yang berkuasa). Ini artinya manusia berlomba dan bersaing meraih kekuasaan. Yang pada gilirannya, berbentur dan saling menjatuhkan tidak dapat dihindari, dan yang menang dalam pertarungan itu hanyalah siapa yang kuat.

Pemaknaan tersebut tidak dapat dilepaskan dari sejarah gerakan pemikiran yang disebut dengan renaissance. Ciri yang menonjol adalah pandangannya yang antroposentrik, yakni meletakkan otonomi manusia di atas segalanya. Kehidupan manusia ditandai dengan sikap materialistik, sekularistik yang tidak memperhatikan dan memedulikan kehidupan batin (esoteris). Meminjam bahasa Alasdair Macintyre (1921) manusia sekadar dimengerti semata-mata faktual. ${ }^{29}$ Akibatnya interaksi sosial yang dihasilkan oleh nilai norma esoteris dalam arti moral yang melekat pada diri manusia tercabut.

Pemaknaan manusia yang distorsif tersebut sudah pasti memberikan efek terhadap tercabutnya moral. Oleh karenanya pemahaman manusia yang demikian, jelas bukan sebuah pilihan untuk mengawal tatanan sosial dalam kehidupan. Sadar akan keberadaan sisi moral dalam diri manusia, Francis Fukuyama dalam karya fenomenalnya The Great Disruption: Human Nature and the Reconstruction of Social Order menyebutkan, "manusia pada dasarnya adalah makhluk sosial yang memiliki kemampuan bawaan untuk mengatasi masalah kerja sama sosial dan menciptakan aturan moral guna mengendalikan pilihan individu. Tanpa harus didesak manusia akan menciptakan ketertiban dengan sendirinya begitu ia memenuhi keperluan hidupnya sehari-hari dan bersinggungan dengan orang lain." ${ }^{30}$ Pendirian ini menegaskan bahwa manusia tidak hanya secara fitrah bermoral akan tetapi dengan moralitasnya manusia mampu menciptakan serangkaian norma informal pemberi teladan yang digunakan bersama dalam mewujudkan tatanan sosial. Tentu saja pemaknaan bahwa manusia secara fitrah bermoral sebenarnya tidak dapat dilepaskan dari unsur agama. Sebab bagaimana pun dalam konsepsi religius, agama merupakan fitrah yang melekat pada diri manusia dan terbawa sejak kelahirannya sebagaimana terekam dalam pernyataan dan kesaksian manusia sebelum hadir di muka bumi, bahwa akan menjadikan Tuhan sebagai Rabb, sebagai Tuhan yang menciptakan, memelihara, menguasai, mengatur kehidupan di alam semesta ini. ${ }^{31}$

${ }^{28}$ Friedrich Nietzsche membagi manusia menjadi dua katagori: yaitu masyarakat elit yang kemudian disebut dengan tuan dan masyarakat yang disebut budak. Nietzsche menghubungkan "kehendak berkuasa" hanya pada manusia dalam katagori tuan atau disebutnya sebagai manusia "Superman". Manusia katagori ini mempunyai kekuatan untuk meraih kekuasaan dan menindas orang lain. Lihat Frans Magnis Suseno, 13 Tokoh Filsafat: Sejak Zaman Yunani Sampai Abad ke19 (Yogyakarta: Kanisius, 1998), h. 198.

${ }^{29}$ Frans Magnis Suseno, Etika Abad ke-20: 12 Teks Kunci (Yogjakarta: Kanisius, 2006), h. 209.

${ }^{30}$ Francis Fukuyama, Guncangan Besar: Kodrat Manusia dan Tata Sosial Baru, terj. Masri Maris (Jakarta: Gramedia Pustaka bekerjasama dengan Kedutaan Besar Amerika Jakarta Freedom Institute, 2005), h. 7 dan 285.

${ }^{31}$ Q.S. al-A'râf/7: 172; Q.S. al-Rûm/30: 30. 
Konsepsi bahwa secara fitrah manusia bermoral merupakan kenyataan yang tidak bisa dilepaskan dari agama seperti paparan di atas, mulanya tidak dipahami dengan baik oleh tokoh sosiolog kenamaan Emile Durkheim (1858-1917). Dengan kata lain, ekspresi moral mengalami penyempitan makna dalam pemahaman positivistik Durkheim. Menurutnya, institusi-institusi moral adalah sesuatu yang eksternal, objektif dan mengikat. Di mata Durkheim yang positivistik, pada dasarnya tidak ada perbedaan antara kekangan moral dan kekangan fisik. Namun komitmen positivistik Durkheim ini menurut Talcott Parsons (1937) mengalami pergeseran teoretis ketika melakukan studi terhadap agama dalam karya The Elementary Forms of Religion Life, Durkheim menyebutkan tatanan moral eksternal -kesadaran kolektif- telah menjadi bagian subjektivitas individu via mekasnisme ritual religius. ${ }^{32}$ Pergeseran teoretis Durkheim ini dapat dipahami sebagai gerak teoretis yang melepaskan diri dari reduksionisme positivistik menuju telaah yang lebih apresiatif terhadap arti penting ritual religius dalam organisasi sosial dan menuju pada satu kesadaran bahwa cara pandang positivistik bukanlah alat ukur yang tepat untuk menentukan rasionalitas agama.

Dengan menyadari arti penting peran agama dalam memberi pancaran aura terhadap moral, terekam dalam jejak perjalanan intlektual-spiritual al-Ghazâlî yang telah menemukan kebenaran hakiki setelah menempuh jalan sufisme. Bagi al-Ghazâlî, sufisme telah membebaskan dahaga dan krisis intlektualnya yang bersifat metodologi (manhajî), sekaligus memberikan kecerahan akan krisisnya spiritual (psikologis), hal itu menjadikannya sangat mengapresiasi sufisme melalui ungkapannya: "Perjalanan sufi merupakan perjalanan terbaik, jalannya adalah jalan benar, dan akhlaknya adalah akhlak yang paling bersih". ${ }^{33}$ Ungkapan tersebut memberikan inspirasi dan peluang yang cukup besar bahwa tasawuf dapat dijadikan sebagai arsitek untuk menciptakan tatanan sosial.

Dalam konteks menjadikan tasawuf sebagai arsitek tatanan sosial, perlu kiranya seseorang untuk kembali memahami konsep "manusia sebagai manifestasi Tuhan" khususnya dari Ibn 'Arabî yang merupakan sufi agung dari Murcia, Andalusia (Spanyol). Menurut Ibn 'Arabî, sebagaimana telah dsinggung sebelumnya, realitas alam semesta dengan berbagai varian dan kemajemukannya ini merupakan bukti ke-Maha-Esa-an Tuhan. Fenomenafenomena di alam kosmos, merupakan penampakan (tajjalî) dari nama-nama dan sifatsifat Tuhan. Dalam ke-Maha-Esa-an-Nya, menurut pandangan Ibn 'Arabî, Tuhan melihat

${ }^{32}$ Sumbangan Durkheim tentang tatanan sosial menurut Talcott Parsons (1937) terbagi dalam dua fase. Fase pertama, yang terdapat dalam karya The Division of Labour in Society, Durkheim menempatkan sumber-sumber stabilitas sosial dalam seperangkat aturan obyektif yang terdapat diluar individu. Pada fase kedua, dalam The Elementary Forms, tatanan sosial mulai mendapatkan akarnya dalam subyektivitas internal individual. Maka makna aturan mengalami perubahan dari ekternal dan obyektif menjadi internal dan subyektif. Lihat: Bryan S. Turner, Agama dan Teori Sosial: Rangka-Pikir Sosiologi dalam Membaca Eksistensi Tuhan di antara Gelegar Ideologi-Ideologi Kontemporer, terj. Inyiak Ridwan Munir (Yogyakarta: IRCiSoD, 2006), h. 86-87.

${ }^{33}$ Abû Hâmid al-Ghazâlî, al-Munqiz min al-Dhalâl (Istambul: Hakekat Kitabevi, 1983), h. 32 . 
diri-Nya yang immateri, sekaligus memperkenalkan diri-Nya. Maka, muncullah asmaasma dan sifat-sifat-Nya.

Asma dan sifat tersebut masih belum bisa dikenal, masih suram, sehingga diperlukan penjernih. Mula-mula alam semesta, binatang, dan malaikat diproyeksikan sebagai cerminan Tuhan. Namun, semuanya belum menjadi cerminan Tuhan yang tepat. Setelah hadirnya Adam (manusia), barulah Tuhan bisa melihat forma atau bentuk-Nya secara tepat. Oleh karenanya, setiap gerak-gerik manusia pada hakikatnya merupakan pancaran diri-Nya. Tasawuf dengan akhlaq (ihsân) merupakan puncak subtansi keislaman. Seorang sufi sejati pasti akan bertemu dalam satu poros hakiki, meminjam filsafat Ibn 'Arabî, yang disebut dengan wahdah al-wujûd. Titik temu inilah yang semestinya harus dikembangkan untuk membangun solidaritas di antara umat yang kosmopolit berdasarkan kesamaan moral (akhlak), dan bukan sebaliknya dengan mencari-cari perbedaan-perbedaan apalagi perbedaan kecil yang hampir pasti dimiliki semua orang sebagai bentuk keanekaragaman.

Keanekaragaman sendiri bagi Ibn 'Arabî, tidak dilihatnya sebagai sebuah sumber keraguan atau kesusahan. Berlawanan dengan itu, ia menganggap hal ini sebagai salah satu dari banyak tanda-tanda bahwa rahmat Tuhan mendahului kemurkaan-Nya, yang membimbing kepada kebahagiaan paripurna setiap makhluk. Karenanya ia menulis, "karena Tuhan adalah akar dari semua perbedaan kepercayaan di alam semesta, dan karena inilah Dia yang membawa kesempurnaan eksistensi setiap hal di alam semesta dalam sebuah susunan yang tak dimiliki oleh apapun juga, setiap orang akan berakhir dengan rahmatNya". ${ }^{34}$

Uraian di atas menunjukkan bahwa pesan-pesan dalam tasawuf memiliki potensi kreatif sebagai arsitek dalam merancang kehidupan dengan mengimplementasikannya melalui dua dimensi yang saling beriringan. Yakni implementasi moral yang memiliki oreintasi keilahian yang diterjemahkan dan dikaitkan dengan orientasi praktis untuk menciptakan kedamaian di antara manusia. Dalam kondisi seperti ini, maka ketika individu melakukan suatu kebaikan moral dalam komunitas, ia tidak semata-mata hanya merasakan sebagai tuntutan hukum normatif dengan segala sanksi yang mengiringinya, tapi juga menghayati sebagai kebaikan yang berasal dari semangat intuisinya. Dengan kata lain adalah menghayati norma-norma dengan seluruh jiwanya sebagaimana ia menghayati ajaran agamanya yang bergetar karena tengah merasakan hidup bersama dalam kesatuan Tuhan.

Sampai di sini, bertasawuf sesungguhnya bukan suatu penyingkapan yang pasif atau apatis terhadap kenyataan sosial. Sebaliknya, nilai-nilai tasawuf memiliki kemampuan untuk mengatasi masalah kerja sama sosial dan menciptakan aturan moral guna mengendalikan pilihan individu. Tanpa harus didesak seorang (baca: sufi) akan menciptakan ketertiban dengan sendirinya begitu ia bersinggungan dengan orang lain. Dengan begitu, bagi seorang sufi, ikhtiar tidak menjadinya prinsip teologis statis. Tetapi, pembumian norma-

${ }^{34} \mathrm{Ibn}$ 'Arabî, al-Futuhât al-Makiyah, vol. III, h. 465.23. 
norma kolektif dalam bermasyarakat ini disadur dari pesan-pesan moral substansial ajaran nilai-nilai tasawuf.

\section{Penutup}

Dalam implementasinya, nilai-nilai tasawuf menempatkan manusia sebagai wakil (khalîfah) dan pusat kesadaran di bawah cahaya keilahian. Hal itu tidak lepas dari konsepsi sufi bahwa manusia bertindak selaku realitas perantara dalam eksistensi tempat Allah berinteraksi dengan kosmos secara langsung yang mengembang kualitas yang melekat pada sifat-sifat Allah. Karenanya, bertasawuf pada hakikatnya menyangkut aktivitas berupa kesadaran manusia paling dalam perihal relasi manusia dengan Tuhan, lingkungan dan sesamanya yang terilhami oleh kualitas asma dan sifat Allah, yang kemudian terwujud dalam tingkah laku sosialnya. Dengan begitu, bertasawuf bukan suatu penyingkapan yang pasif atau apatis terhadap kenyataan sosial, sebaliknya pengenjawantahannya adalah bagaimana pemahaman atas kualitas ketuhanan tersebut mampu ditransformasikan untuk mengukuhkan eksistensi kemanusiaan dalam realitas "kebumiannya." Dari Tuhan menuju bumi, dari zat Tuhan menuju kepribadian manusia, nilai-nilai kemanusiaan diderivasi dari sifat-sifat Tuhan, dari kekuasaan Tuhan menuju kemampuan berpikir manusia, dari keabadian Tuhan menuju gerakan kesejarahan manusia, dari eskatologis menuju masa depan kemanusiaan. ${ }^{35}$ Kondisi itu menempatkan pancaran keilahian menjadi tidak ternafikan dalam konteks penajaman realitas kemanusiaan. Dengan bahasa lain, bertasawuf sejatinya membimbing manusia ke dalam harmoni dan kedamaian total. Interaksi kaum sufi dalam semua kondisi adalah dalam harmoni dan kesatuan dengan totalitas alam, sehingga perilakunya tampak sebagai manifestasi cinta dan kepuasan dalam segala hal.

\section{Pustaka Acuan}

Al-Attas, S.M.N. The Concept Education in Islam. Kuala Lumpur: ISTAC, 1991.

Anshari, Endang Saifuddin. Ilmu, Filsafat dan Agama. Surabaya: Bina Ilmu, 1987.

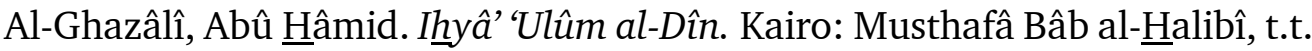

Al-Ghazâlî, Abû Hâmid. Al-Munqidh min al-Dhalâl. Istanbul: Hakekat Kitabevi, 1983.

El Fadl, Khaled Abou. Speaking in God's Name: Islamic Law, Authority and Women. England: Oneworld Publications, 2003.

'Afîfî, Abû al-Alâ. "Tasdîr “Âmm," dalam Abû ㅂâmid al-Ghazâlî. Mishkat al-Anwâr. Kairo: al-Dâr al-Qawmîyah, 1964.

${ }^{35}$ Hasan Hanafi, Islam in the Modern World: Ideology and Development (Kairo: Egyptian Associated Company, 200), h. 11. 
Fukuyama, Francis. Guncangan Besar: Kodrat Manusia dan Tata Sosial Baru, terj. Masri Maris. Jakarta: Gramedia Pustaka bekerjasama dengan Kedutaan Besar Amerika Jakarta Freedom Institute, 2005.

Hanafi, Hasan. Islam in the Modern World: Ideology and Development. Kairo: Egyptian Associated Company, 2000.

Harnock, Justus. Harnock, Kant's Theory of Knowledge, trans. M. Holmes H. London: Macmillan, 1968.

Husserl, Edmund. Ideas: General Introduction to Pure Phenomenologi. New York: Collier Books, 1962.

Ibn 'Arabî, Muhy al-Dîn. Al-Futûhât al-Makkiyah, Vol. III. Kairo: al-Hay'ah al-Misriyah al'Âmmah li al-Kitâb, 1972.

Al-Jâbirî, Muhammad 'Abîd. Naqd al-'Aql al-'Arabî, Bunyat al-'Aql al-'Arabî: Dirâsah Tahlîlîyah Naqdiyah li Nazm al-Ma'rifah fî al-Thaqâfah al-Áabah. Beirut: Markaz al-Tsaqafî al-Arabî, 1993.

Khun, Thomas S. The Structure of Scientific Revolution. Chicago: the University of Chicago, t.t.

Lawrence, Bruce B. Islam Tidak Tungggal: Melepaskan Islam Dari Kekerasan, terj. Harimukti Bagoes Oka. Jakarta: Serambi Ilmu Semesta, 2004.

Mahmûd, 'Abd al-Qâdir. Al-Falsafah al-Sûfiyah fí al-Islâm. Kairo: Dâr al-Fikr al-Aarabî, 1967.

Peusen, CA. Van. Susunan Ilmu Pengetahuan. Jakarta: Gramedia, 1989.

Al-Qushayriyah, Abû Qâsim. al-Risâlah al-Qushayriyah, diedit oleh 'Abd al-Qâdir Mahmûd. Kairo: Dâr al-Kutûb al-ㅍaîtsah, 1974.

Seere, Douglas V. "Mysticism” dalam Hand Book of Christion Theology New York: World, 1958.

Siradj, Said Aqil. Ma'rifatullah: Pandangan Agama-Agama, Tradisi dan Filsafat. Jakarta: éLSAS, 2003.

Suseno, Frans Magnis. 13 Tokoh Filsafat: Sejak Zaman Yunani Sampai Abad ke-19. Yogjakarta: Kanisius, 1998.

Suseno, Frans Magnis. Etika Abad ke-20: 12 Teks Kunci. Yogjakarta: Kanisius, 2006.

Titus, Horald. Persoalan-Persoalan Filsafat, terj. M. Rasjidi. Jakarta: Bulan Bintang, 1984.

Turner, Bryan S. Agama dan Teori Sosial: Rangka-Pikir Sosiologi dalam Membaca Eksistensi Tuhan di antara Gelegar Ideologi-Ideologi Kontemporer, terj. Inyiak Ridwan Munir. Yogyakarta: IRCiSoD, 2006. 